\title{
CLIMATE CRISIS AND SOCIAL WORK: LACK OF CLIMATE CRISIS EDUCATION IN SOCIAL WORK CURRICULUM
}

\author{
By \\ Tasneem Zaman, BSW, University of Calgary, 2016 \\ An MRP \\ presented to Ryerson University \\ in partial fulfillment of the \\ requirements for the degree of \\ Master of Social Work \\ In the Program of \\ Social Work
}

Toronto, Ontario, Canada, 2019

(C) Tasneem Zaman 2019 


\section{AUTHOR'S DECLARATION FOR ELECTRONIC SUBMISSION OF An MRP}

I hereby declare that I am the sole author of this MRP. This is a true copy of the MRP, including any required final revisions.

I authorize Ryerson University to lend this MRP to other institutions or individuals for the purpose of scholarly research

I further authorize Ryerson University to reproduce this MRP by photocopying or by other means, in total or in part, at the request of other institutions or individuals for the purpose of scholarly research.

I understand that my MRP may be made electronically available to the public. 


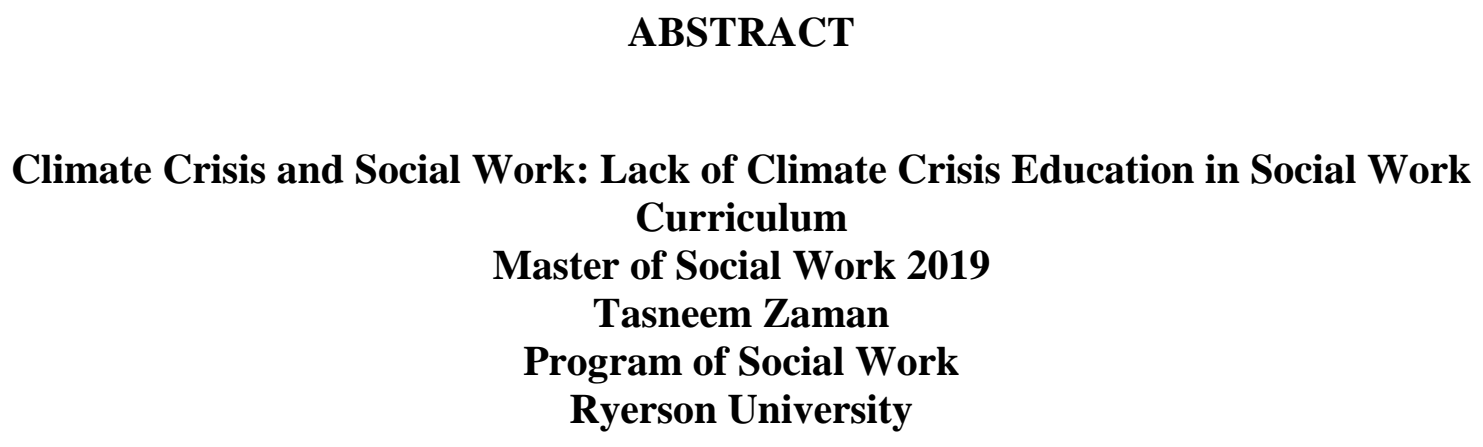

This paper argues that social work curriculum ignores the pressing matter of the ongoing global climate crisis. Using the theoretical frameworks of anti-racism and anti-colonialism, I propose four ways to deal with this curricular gap in social work, which are the following: 1) to insert ethical obligations on the part of social workers to address climate change and environmental justice within the social work code of ethics, 2) to expand the person-in-environment focus to include nature and environmental justice, 3) to embrace a transformative learning paradigm, and 4) to implement a mandatory course on natural disaster management. 


\section{Table of Contents}

Introduction 2

$\begin{array}{ll}\text { Literature Review } & 19\end{array}$

$\begin{array}{ll}\text { Theoretical Framework } & 30\end{array}$

Discussion $\quad 34$

$\begin{array}{ll}\text { Conclusion } & 43\end{array}$

$\begin{array}{ll}\text { Reference } & 46\end{array}$ 
"The greatest threat to our planet is the belief that someone else will save it."

Sir Robert Swan

\section{Introduction}

This Major Research Paper is inspired by who I am and what is happening to my home and place of birth in Bangladesh. Due to climate change and the resultant rising water levels, oceans could flood 17\% of Bangladesh's land and displace about 18 million of its citizens by 2050 (Lakritz, 2019). As the people of Bangladesh are forced to migrate and integrate into other countries, they will need to learn the new languages which raises the risk of the loss of languages and cultures of Bangladesh. This loss can already be seen with first generation and secondgeneration youth in my community. More and more of us readily speak a mix of Bengali and English. When speaking to youth we use English more than Bengali. I, like many other secondgeneration Bengali youth, cannot write or read in our language. The thought of losing our language will lead to a cultural loss, I fear. Land has profound connection to culture and ways of being. This has been clear when looking at the aftermath of many countries after colonization.

Increasingly links have been made between climate change and mental health issues. Sixteen-year-old climate activist, Greta Thunberg, the inspiration behind Friday for Future movement sweeping the globe explained in her 2018 TED Talk that knowing about climate change was hell on her young psyche. She explained, "When I was 11, I became ill. I fell into a depression. I stopped talking and I stopped eating. In two months, I lost about 10 kilos of weight" (Pearl, 2017, p.12). Then she came out of her despair and found a voice when she decided to strike-refusing to go to school until the world demonstrated that it's "getting its shit together" (Pearl, 2019, p. 12). 
I can relate with Greta around the feelings of depression, anxiety and a sense of hopelessness as I watch the unfolding of destruction that is taking place in Bangladesh and around the globe. As a child I watched a lot of National Discovery and was absolutely captured and in love with the beauty and vastness of earth. I have a deep affection for animals and plants, having grown up with animals who taught me empathy and unconditional love. I also grew up running barefoot in fields enjoying the touch of earth, climbing trees and finding peace amongst them. I cannot describe in words the sense of peace and calming effect trees and animals have on my wellbeing. Thus, as the climate crisis exacerbates, I feel extreme sadness, anger, and frustration around the lack of political commitment to addressing the devastating impacts of the climate crisis. It enrages me that profitability of the land is the number one priority of many corporations and governments.

The climate crisis has taken a toll on my mental health, which is not uncommon. A rising awareness around the term ecological grief is coming to surface to capture this phenomenon. Climate grief speaks to the grief felt in response to experienced or anticipated losses in the natural world (Cunsolo \& Ellis, 2018). Given that we are living in a time of extraordinary ecological loss, and that these losses will not end anytime soon, ecological grief will become the norm for people trying to process and digest the impacts of the crisis. There is an intense emotional and psychological pain, particularly for people who remain deeply connected to, and observant of, the natural world to bear witness to ecological losses personally, or witness the suffering encountered by others (Cunsolo \& Ellis, 2018).

I have realized that my work around the climate crisis, needs to centre the voices of Indigenous peoples, land sovereignty and work alongside Indigenous leaders. Indigenous people with their deep connection to the Earth and living off the earth are more directly impacted by the 
crisis. My work needs to include, and centre Indigenous sovereignty, rights to land without appropriating their knowledge systems. Social workers working on the climate crisis need to invite and work alongside Indigenous people.

As I watch the state of the earth and the lack of political action due to the capitalistic agendas of governments and corporations, I feel angry, frustrated and hopeless. I get a deep rush of sorrow from knowing that millions of species of plants and animals are at the threat of extinction. I am angered that environmental racism exists, and that marginalized and racialized people will end up paying the most for the climate crisis. Moreover, I feel a deep sense of loss and fear of no longer being able to return to Bangladesh. I am worried that with the loss of place and land; culture and language will be lost as people try to assimilate to foreign places. Moreover, Bangladesh has one of the most fertile lands in the world, and losing that space saddens me as a great loss to the biodiversity of the planet.

These feelings of loss and grief also stir up the desire to bring the climate crisis at the forefront of my work as a social worker and bring awareness around the immediacy of social workers to deepen their work around the crisis. This paper has been one of the outlets for me to introduce the need and urgency of why social work is needed to address the climate crisis, and how critical it is to include the natural environment into our education and curriculum. In my own experience as a social work student, the natural environment and climate change were hardly ever a part of the curriculum.

Fueled by my passion as a person born in Bangladesh and my love for animals and nature, I had initially designed a qualitative research study that was aimed at interviewing students around their social work education experience, and to query if the climate crisis was discussed in their 
courses. I submitted a protocol to the Ryerson Research Ethics Board and my study was successfully approved. I was passionate about wanting to highlight the voices of these students and their thoughts and feelings about social work education and the environment. However, much to my dismay, due to the tight timelines I was not able to complete the study. Yet, I remain undeterred and wish to follow my heart and passion for writing and researching about the climate crisis, especially as my home country of Bangladesh is literally at stake.

Therefore, in this paper, I will build upon my passion for addressing the climate crisis, particularly as a social worker. I will argue that current social work programs in Canada do not include environmental concerns in the curriculum. I will also argue that this gap in the curriculum can be addressed in three ways: 1) to insert ethical obligations on the part of social workers to address climate change and environmental justice within the social work code of ethics, 2) to expand the person-in-environment focus to include nature and environmental justice, 3) to embrace a transformative learning paradigm, and 4) to implement a mandatory course on natural disaster management.

The Council on Social Work Education, CSWE, (Dewani, 2011), The United Nations Secretary General, Ban Ki-Moon (Sturmer, 2014), along with 90\% of scientists around the world identified climate change as the single greatest natural threat to humanity of the 21 st century (Cumby, 2016). Attempts to improve social conditions may be lost if society itself lacks clear air, drinkable water, and adequate food. It is now well understood that the key issue is not a lack of solutions to deal with the climate crisis, rather, it is a lack of political initiative to put these solutions into action (Semeniuk \& McCarthy, 2015). In Canada, little action has been taken to address the urgency of the climate crisis. Even within the last 10 years, according to Environmental Defence (2015), Canada's commitment to addressing the climate crisis at the Paris agreement in 
2005 was the most inadequate of all the G7 countries. Canada committed to reducing greenhouse gas emissions by $30 \%$ from the 2005 emissions level by the year 2030 (Cumby, 2016). It only committed certain sectors to meet this goal, excluding the highest greenhouse gas polluter in all of Canada, the Alberta tar sands, which have increased greenhouse gas emissions rate by $79 \%$ since 2005 (Grandia, 2015).

Moreover, the Canadian government spent $\$ 4.5$ billion dollars to purchase the Trans Mountain pipeline (Tasker, 2019). The purchasing of the pipeline can be traced back to the Canada-China Foreign Investment Promotion and Protection Agreement (FIPA), which was ratified in 2014 and negotiated by the previous Harper government. It was passed without a vote in Parliament (Livesey, 2017). The recent study done by du Pont and Meinshausen (2018) found that Canada, along with Russia, China, Argentina, Saudi Arabia, South Africa and a dozen other countries, are dangerously contributing to the global temperature rise, and is on course to vastly exceed the 1.5 degrees Celsius, the moderately safe level of climate change identified by the Intergovernmental Panel on Climate Change (IPCC). Canada's current climate policies are insufficient and are in fact leading to an increase in global temperatures by a catastrophic 5 degrees Celsius by the end of the century (Syed, 2018). Climate change has been debated and doubted by capitalistic agendas that have halted the progress of political and corporate action by many countries, especially developed nations.

As the IPCC (2014b) concluded, we need a transformation in the broader social consciousness on these issues in order to put increasing pressure on governments and corporations to immediate and appropriate actions. Social workers are key stakeholders in advocating and creating this transformation of social conscience. However, regardless of the increasing links, and evidence of the many ways that the climate crisis is threatening the livelihood of people and their 
wellbeing, social work remains silent to addressing these challenges and exploring ways to move forward (Drolet, Dennehy, Taylor, \& Wu, 2015). Coates (2011) asserts that "large majority of social workers, like our society in general, take 'nature' for granted and have not been sensitive to the relevance of environmental issues, particularly for social welfare, human rights and social justice" (p.1). In fact, a nationwide survey of over 400 members of the National Association in the United States of America (US) found that social workers are no more knowledgeable or climate conscious as the general population (Melekis \& Woodhouse, 2015). Moreover, the profession has not embraced the need to incorporate environmental concerns in their practice or education (Melekis \& Woodhouse, 2015).

The climate crisis is a significant global threat to humanity that requires social work solutions and action, yet social work remains silent on this issue in the broader discourse. For the purposes of this research, social work "action" refers to conducting research, advocacy work (macro), community development (meso), and clinical interventions (micro). Moreover, climate change will be referred to throughout the paper as climate crisis since the word "change" can allude to gradual changes over time and does not capture the state and severity of the issue. By stating the issue of environmental degradation as a crisis, I hope to instill a sense of emergency, and urgency to the issue.

\section{Definition of Climate Change}

The IPCC, initiated by the United Nations in 1988, is at the forefront in tracking and researching impacts of climate change and potential solutions. The IPCC consists of thousands of researchers from six of the seven continents across the globe. In their recent report, they defined climate change "as a change in the state of the climate that can be identified (e.g., by using 
statistical tests) by changes in the mean and/or the variability of its properties, and that persists for an extended period, typically decades or longer" (IPCC, 2014a, p. 5). Seventy-one researchers from 29 countries concluded that climate crisis is producing negative impacts across the globe and if left untreated, by the year 2030 devastating and irreversible effects will follow (IPCC, 2014a). These effects include, but are not limited to: food insecurity, complete loss of natural resources, genocide of entire habitats and ecosystems, displacement of people and wildlife, loss of biodiversity, loss of marine and coastal ecosystems, breakdown of infrastructure and critical services, and increased morbidity and death (IPCC, 2014a).

\section{Impacts of the Climate Crisis}

The climate crisis is having a varying range of noticeable effects around the world. As the climate crisis has barely a presence in social work curriculum, I wish to highlight the effects that are readily associated with the climate crisis.

\section{Extreme Heat}

Extreme heat waves are occurring more frequently throughout the world. Heatwaves naturally occur in summertime; however, heatwaves are happening earlier, more frequently and lasting longer than ever before. This year heat wave records were broken in France, Switzerland, Austria, Germany, Spain, India, and the Arctic (Ifran, 2019).

France had to administer red alerts in several areas, many schools were closed, exams were postponed and health minister Agnès Buzyn warned that everyone is at risk (McGrath, 2019). Similarly in early June 2019, an intense heat wave scorched northern India. Some regions 
experienced temperatures surpassing $45^{\circ} \mathrm{C}\left(113^{\circ} \mathrm{F}\right)$ for the better part of three weeks. On June 10 , Delhi reached its hottest day on record for the month, reaching $48^{\circ} \mathrm{C}\left(118^{\circ} \mathrm{F}\right)(\mathrm{Pti}, 2019)$.

Not far from home in Canada, 34 deaths occurred in southern Quebec related to the heat wave that persisted for three weeks (Quackenbush, 2018). With the increasing temperatures, these hotter summers will be the norm, leading to many negative health outcomes. These heat waves “... are proof that climate change is striking everywhere, and it is a serious public health threat" warned Antonio Guterres, U.N. Secretary-General (Conley et al., 2019, p.12). With higher temperatures, social workers will have to support people who lose loved ones due to heat strokes, and families and individuals who are not able to adapt financially to mediate the impacts of rising temperatures. For example, people who do not have access to air-conditioned facilities or homes will be vulnerable to death caused by heat stroke. To date, social work has said very little about this impending role of social workers.

\section{Wildfires}

With higher temperatures and drier environments, the rise in wildfires have undoubtedly increased (Flannigan, 2009). Destructive fires have an enduring impact on the community and lingers long after the incident. The extraordinary danger and lasting impacts of wildfires cost tremendous strain on the economy. Over the last decade Canada spent 500 million to one billion dollars to combat wildfires, and this figure is predicted to double according to climate change projections (Natural Resource of Canada, Cost of Fire Protection, 2019). The Fort McMurray fire in 2016 is an example of the damage caused by wildfires. This fire caused the evacuation of almost 90,000 people and quickly became the most expensive natural disaster in Canadian history, destroying 2400 buildings and causing about $\$ 10$ billion in damage (Forest Fires and Climate 
Change, n.d.). With increasing cost to the economy, governments pay spend less on social service programs or education to mediate the cost. In times of these crises, social workers will be at the forefront in supporting families and individuals displaced due to natural disasters. It is not enough to just provide the immediate basic needs to people displaced by environmental disasters, but to challenge the actions taken by governments and corporations that contribute to the climate crisis. This challenge is important to help reduce the number of casualties in the future.

\section{Drought}

The trees in California's mountain forests have roots that can draw water from as deep as 5 to 15 meters below, which historically protected them against the worst multi-year droughts. However, Goulden and Bales (2019) found that the severity of California's 2012-2015 dry-spell exceeded this safety margin. From 2012 to 2015, the entire state experienced a crippling drought, but it was especially severe in the southern Sierra Nevada. The four-year period was the driest in the past century, combined with below-average precipitation and above-average warmth extending year after year (Goulden \& Bales., 2019). Goulden and Bales (2019) conclude that the climate crisis will intensify evapotranspiration and ground moisture overdraft, when more water is taken out of the soil than is replaced by precipitation, resulting in a 15 to 20 percent increase in tree death for each additional degree of warming.

As reported by the Canadian Drought Monitor, Canada's official source for monitoring and reporting droughts, droughts have increased dramatically in terms of intensity, frequency, and size between 2002 and 2015 (Government of Canada, 2015). In July 2005, Canada experienced some small patches of "abnormally dry" conditions across the country, with very few instances of “moderate drought" (Cumby, 2016). By July 2010, abnormally dry conditions had spread across 
almost the entirety of British Columbia, Alberta, and Québec, nearly half of Saskatchewan and Ontario, and the central portion of Manitoba (Cumby, 2016). Additionally, droughts in the category of "severe drought" started to spread across B.C., Alberta, and Ontario. By July 2015, there are significantly more instances of abnormally dry conditions spreading up through the territories, as well as increased instances of moderate drought, severe drought, extreme drought, and the first instances of "exceptional drought" - the highest drought rating possible - throughout Canada (Cumby, 2016).

\section{Extreme precipitation}

According to the Union of Concerned Scientists (2011), a warmer climate leads to increased evaporation from the land and sea, which results in increased precipitation. In warmer climates, this leads to extreme rainfall and, as a result, extreme flooding. Zhang (2016) noted that major floods only used to happen once every hundred years, however, major floods are occurring every ten to twenty years. In 2013, Alberta, Canada experienced devastating flood that affected a quarter of the entire province, resulting in the largest evacuation in Canada in sixty years (Government of Canada, 2014). Over 100,000 people were displaced from their homes and it became the costliest disaster in Canadian history at six billion dollars. Similarly, in 2014, Baltimore also experienced a severe flood that resulted in the collapse of an entire street, washing away cars and flooding the railroad tracks underground (Hermann, 2014). With more people displaced out of their homes, social workers will need to support individuals to deal with loss financially and emotionally. Furthermore, social workers will need to provide adequate counselling to those that experience trauma from the disasters. 
In colder climates, severe precipitation leads to extreme snowfall. Alarmingly, in December 2013, Cairo Egypt faced four inches of snow for the first time in 112 years (Elgot, 2013). Similarly, in 2015, Boston, USA, experienced its snowiest month on record (Almasy \& Karimi, 2015), resulting in the collapse of an apartment complex roof and displacement of 30 people. That same storm impacted New Hampshire, where a portion of a strip mall also collapsed. January 2016, New York, Washington, and Baltimore, USA, all received record levels of snowfall, at two to three feet of snow each, and Philadelphia also set a record, at just under two feet of snow, resulting in 48 deaths, power outages, buried vehicles, coastal flooding, beach erosion, and roof collapses (Rathbun, 2016). In Canada, Newfoundland in 2015 experienced record-breaking snowfall, resulting in power outages and closures across St. Johns (The Weather Network, 2015). These examples highlight the devastating and costly nature of these extreme weather events. With an increase in snowfall, and colder weather, people impacted by homeless will have an increasingly hard time finding shelter. This year, Toronto opened up 35 new warming centre spaces to try and support those out of shelter (Rizza, 2019). Similarly, Ottawa is experiencing a mass shortage of shelter space (Osman, 2018). With more people displaced due to natural disasters and increase in colder temperature cities will struggle to shelter people. Social workers will be at the heart of finding shelter and support for these people.

\section{Decreased food and water supply}

Extreme droughts have devastating impacts on food production, food security, and availability of drinking water. In Brazil, the drought reduced the drinking water reserves to 10 percent of capacity and negatively affected their vegetation yields (Carlowicz, 2015b). Similarly, the city of Henan in China was significantly affected by drought which severely impacted the yield of soybeans, barley, and rice worldwide, reducing global exports significantly, as the city is a huge 
supplier of these crops (Reklev, 2014). In Russia, as a result of the drought, grain exports were banned in order to preserve food supply domestically, which drove up the global price of wheat by 90 percent (Kramer, 2010). In Syria, the drought resulted in the loss of 80 percent of their cattle livestock by the year 2009 (National Public Radio, 2013). NPR (2013) argued that this was one of the main catalysts to inciting the civil war that is still happening in Syria today. In Mongolia, drinking water was removed from 300,000 citizens. Throughout Canada, many people have been feeling the touch of rising food costs ( $\mathrm{Li}, 2016)$, leading a significant number of people to reduce meat consumption (61\%), reduce vegetable and fruit consumption (42\%), and choose unhealthier, cheaper food alternatives (40\%) (Ferreras, 2016). Furthermore, more people are opting to eat at home, which has had negative impacts on local economies (Li, 2016).

As a result of extreme heat and droughts, food and water availability and access have been severely limited across the globe, driving up prices and, thereby, causing people to make less healthy choices when it comes to nourishing their bodies and families, as well as further limiting access to food and water by vulnerable and marginalized populations (Clapp, 2011; Clapp \& Cohen, 2009; IPCC, 2014a), which has resulted in increased morbidity and mortality rates and war.

\section{Impacts on ecosystems}

"The evidence is crystal clear: Nature is in trouble. Therefore, we are in trouble," said Sandra Díaz, one of the co-chairs of the Global Assessment Report on Biodiversity and Ecosystem Services (Leahy, 2019, pp. 2). Many species have shifted their activities, geographic ranges, migration patterns, and species interactions, which have led to significantly higher rates of species extinctions (IPCC, 2014a).The UN released an extensive report, a review of about 15,000 scientific 
and government sources and compiled by 145 expert authors from 50 countries, highlighting the devastating impacts of human activity is pushing the extinction of one million species in the new few years (Leahy, 2019). This global report is the first comprehensive look in 15 years at the state of the planet's biodiversity and for the first time, Indigenous and local knowledge as well as scientific studies. They ranked the major drivers of species decline as land conversion, including deforestation; overfishing; bushmeat hunting and poaching; climate change; pollution; and invasive alien species (Leahy, 2019).

The tremendous variety of living species, at least 8.7 million, but possibly many more that make up our 'life-supporting safety net' provide our food, clean water, air, energy, and more, is at the threat of being killed', said Díaz, an ecologist at the National University of Cordoba in Argentina (Leahy, 2019, p.?). They explained that "Not only is our safety net shrinking, it's becoming more threadbare and holes are appearing" (Leahy, 2019, p. 4). A 40-page document, the Summary for Policy Makers, was released on May 6 (2019) in Paris (Leahy, 2019) warning that the extinction of species will pose detrimental consequences for human beings as well as the rest of life on Earth.

\section{People and Vulnerable Communities}

As discussed, climate change induced extreme weather events have led to mass displacement of people, negatively affected food and water security and financial strain on cities/countries. Climate induced weather changes have led to increased morbidity and mortality. According to the CDC (2015), climate change has already led to an increasing amount of heat related illnesses, injuries, and deaths due to extreme weather, as well as increasing asthma and cardiovascular disease due to air pollution. There has also been an increasing amount of reported 
cases of malaria, dengue, encephalitis, hantavirus, Rift Valley fever, Lyme disease, chikungunya, and West Nile virus due to changes in vector ecology, as well as increasing cases of cholera, cryptosporidiosis, campylobacter, leptospirosis, and harmful algae blooms due to water quality impacts (Cumby, 2016). In addition, there have been increases in reported cases of malnutrition and diarrheal disease due to water and food supply impacts, as well as increased forced migration, civil conflict, and mental health impacts due to environmental degradation (Cumby, 2016). According to McMichael (2015), extreme weather events result in increasing infectious disease outbreaks as "microbes, vectors and reservoir animal hosts exploit the disrupted social and environmental conditions of extreme weather events" (p. 543). These outbreaks affect the air, land, and water, which, in turn, affect the food supply. Humans become increasingly susceptible to climate---related disease and death, as a result.

In the next section, I will present a literature review that I undertook in efforts to build a foundation for researching the issue of the climate crisis, particularly in relation to social work education. 


\section{Literature Review}

\section{Summary of Literature}

The findings of my literature review will be divided into two sections. The first section discusses the gaps in education around climate change in social work while the second explores the negative impacts of climate change on communities. Half of the literature I reviewed spoke to the limitation of education and action of social work around climate justice. The three themes that arose out of my review of the literature were: (1) lack of formal education and action of social workers around climate change, (2) expanding the narrow perspective of 'person in the environment' to a holistic concept that includes the physical environment, and (3) radical change in the current dominant paradigm of social work an. Although the International Federation of Social Workers (IFSW) recognizes the link between the physical environment and social wellbeing and advocates for the physical environment being an essential component in social work, there is reservation on the part of social workers in embracing environment as a domain of practice. This highlights the lack of visibility in the profession in adopting changes and being involved in decision-making in policy around environmental justice (Alston, 2015). Harris and Boddy (2017) found that out of 937 social work course descriptions from Australian educational institutions, only four course descriptions mentioned words related to natural environment and sustainability.

Similarly, Appleby, Bell \& Boetto, (2017) found a limited number of initiatives taken by local governments in Australia in adopting and implementing programs related to climate change 
(outside the typical regime of recycling, reducing and reusing). Furthermore, climate change adaptations related to vulnerable groups, such as seniors, were hardly addressed. According to Mukheibir, Kuruppu, Gero, \& Herriman (2013), a range of coordinated strategies are needed to effectively address the impacts of climate change. Governments need to encourage the implementation of socially-based climate change adaptation initiatives, such as instilling funding that targets capacity and resilience building of communities. The current divisive discourse of the climate crisis being exasperated by human activity versus being a natural thematic cycle, is a major factor in contributing to the lack of action regarding climate change on the part of governments, organizations, and social work.

The second set of articles I reviewed studied the impact of climate change on communities. Two broad themes emerged from the literature: (1) climate change disproportionately impacts vulnerable groups, and (2) frequent severe weather fluctuation creates stress on economic, social and emotional wellbeing. An example that captures these two themes is the literature around the Inuit population in Canada. Willox et al. (2013) found that Inuit communities' ability to predict weather patterns through traditional ways have been severely reduced due to climate changes being more frequent and dramatic. Shorter winters are leading to quicker ice melts resulting in changes in hunting patterns with less time to spend on land and hunt (Willox et al., 2013). Species are negatively impacted by weather patterns resulting in communities having to rely on non-local foods from markets, which are extremely financially burdensome. Often women in the community skip meals to ensure family members have enough to eat (Beaumier \& Ford, 2010). One participant described that "Inuit people live on ice, ... they're people of the ice" (Willox et al., 2013, p. 20). As such, the ice melts are threatening the way of life of Inuit people.

\section{Paradigm and Discipline}


When reviewing literature dealing with gaps in social work education around climate change, all studies adopted a positivist paradigm (Appleby, Bell, \& Boetto, 2017; Bowles, Boetto, Jones, \& McKinnon, 2018; Harris \& Boddy, 2016; Ramsay \& Boddy, 2017). Although, a positivist paradigm is helpful for the initial phase of studying the gaps in literature, policies, and action around climate change, it does not address why the gaps exist in the first place. When adopting an interpretive approach, conversations need to directly link climate change and social work for students, practitioners, and educators in order to facilitate greater understanding of the issues of climate change. This is critical for generating more awareness and discourse around the environmental crisis.

For literature evaluating the impacts of climate change on communities, interpretive paradigms were utilized to understand the stories of communities directly impacted by climate change. These studies were drawn from a variety of disciplines, such as social work, developmental studies, and environmental conservation, This form of knowledge production challenges the dominant western ideology of "valid" knowledge through broadening the concept of truth produced by researchers and peer reviewed articles, as stressed in positivist paradigms (Neuman, 2006). The interpretive paradigm looks for multiple truths that are formed through social constructs, such as culture, values and experiences. The paradigm aims to understand human sense making in its full complexity (Rubin \& Babbie, 2013).

However, in some of the studies I reviewed there was an absence of voices that would further enrich the narratives around how climate change impacts vulnerable populations. Boetto and McKinnon (2013) interviewed rural women in Australia around the negative impacts of climate change. Only women that sought support from women's services program and women activists were interviewed. This only touches upon a surface level of the problem as it did not 
include women who did not seek support or sought support and were not satisfied with the services. Interpretive methods are beneficial to capture lived experiences; however, researchers need to be highly critical of which voices are being included, excluded and what that means for the findings generated. It is critical to involve communities in mobilizing and advocating for change, which the transformative paradigm strives to implement. By having communities involved, solutions and recommendations are coming straight from the people that are highly impacted. Furthermore, by having enough people demand for change, will bring the need for action around climate change at the heart of discussion in governments.

Willox et al., (2013) and Berkes and Jolly (2001) grounded their research in the transformative paradigm. These studies were highly anti-oppressive as the knowledge production was co-created with researchers and community members. Community leaders and members were involved from creating the research questions, to facilitation of workshops, to production of the video, to confirming and approving the analysis of data. This form of research resists the typical mainstream approaches to conducting research more than the interpretive paradigm. Researchers utilizing a transformative paradigm not only learn about how people are adapting and being impacted by climate change but were actively including and empowering community members to identify strengths and resiliency of their communities. In doing so, communities are seen as change makers and can Furthermore, they are producing a product, a video in this case, to assist in changing policy development by the government (Berkes \& Jolly, 2001; Willox et al., 2013.)

\section{Methodology and Methods of Data Collection of Literature Reviewed}

\section{Quantitative}


Five articles I reviewed used quantitative methodology to gather data around the gaps of climate change in the educational curriculum of social workers. The articles utilized content analysis to highlight the gaps in social work curriculum around the natural environment. Due to the lack of knowledge and focus on climate change in social work, content analysis is appropriate to gage the gaps around this issue through highlighting the lack of work, practice and theoretical adoption of the climate crisis in literature, codes of ethics and education curricula. One of the limitations of the content analysis produced by the researchers pertains to the type of literature and documents that were analyzed. Literatures reviewed and preferred were academic, peer reviewed and written in English. This excludes other forms of knowledge, some racialized people, nonhumans and the natural world (Ramsay \& Boddy, 2017).

\section{Mixed Methods}

Some of the literature I reviewed used open ended and closed ended surveys to identify themes and basic demographics of communities to further understand the relationship that gender, income and social positions have in conjunction with people's ability to adapt to climate change (Arsenault, Azam, \& Ahmad, 2015; Crawford et al., 2015). A mixed method approach allows researchers to gain greater depth into the phenomena of interest using triangulation. Triangulation allows researchers to look at a topic through multiple lenses by utilizing different techniques of both quantitative and qualitative methods (Creswell \& Clark, 2017). Although the researchers identified using a mixed method approach, findings were presented mainly in a quantitative manner, depriving the research of the rich narratives of participants and resorting to stripped down and summarized versions of people's experiences. 


\section{Qualitative}

The literature review heavily adopted qualitative method to understand the stories of people whom are directly impacted by environmental change. Interviews dominated the choice of data collection. Other methods included case studies, interpretive ethnography, and action research.

All interviews mentioned in the literature were semi-structured to allow for participants to direct and engage in conversations that were informal. The semi-structured format allowed for the flexibility of participants to tailor and delve deeper into their narratives but still maintained an underlying structure to guide their stories. A critique of the interviews lies in the presentation of results, which were done in a highly quantitative manner. Dialogues were summarized into brief sentences, charts and tables that populated the result section and no references were made as to whether participants had access to the analysis of the data, except for the two transformative studies (Berkes \& Jolly, 2001; Willox et al., 2013,).

Case studies were conducted with rural women in Australia, people in Guelph, Ontario and the char people of Bangladesh. Char are vegetated islands within riverbanks and are difficult to access. People who live on char are subjected to extreme and hazardous conditions of frequent and intensive flooding and erosion (Sarker, Huque, Alam, \& Koudstaal, 2003). Case studies allow for in depth analysis of experiences that certain communities face; case studies can be especially insightful where there is a lack of previous knowledge or research available (Creswell \& Clark, 2017). However, there was a severe lack of inclusion of racialized and Indigenous people, who are the most vulnerable to the impacts of climate change. The literature review demonstrated that the voices of white, middle class individuals are valued over that of racialized counterparts, which perpetuates an epistemic violence of sorts against marginalized populations. The exclusion of these 
racialized and Indigenous voices can be linked to colonization and white supremacy. It is paramount to include marginalized voices to capture the wide spectrum and complexities that climate change presents for minority groups. In terms of presentation of findings, data was again presented through categorized themes and brief, inferred summarized descriptions of participants' experiences.

Lastly, some literature reviewed used an action/practice research methodology and delved into the experiences of Inuit communities. Semi-structured interviews, workshops, land-based learnings, incorporated to teach non-Indigenous researchers the culture and complex ties Inuit peoples have with land, and the production of a video were all co-directed by the participants. Rich quotations were produced through talking circles and directly quoted, in an anonymous manner. Willox et al. (2013) quoted the following:

Nature is to us another person. This other being that you connect with and you respect. And you just want to be there amongst it...You give it the respect; it'll give you the respect back...It has to be respected. You can't control it and the truth of the matter is that the land is really, really, special to me... besides my family, I would die for my land. (p. 19)

By including direct narratives, the perspectives, history and culture of Inuit communities are centred. There is a deeper context and emotional undertone that allows readers to empathize and better understand how the melting of ice emotionally affects Rigolet people and their sense of identity. If the findings were incorporated in the same manner as the other literatures, categorizing information into themes and summarized versions of stories into charts, the rich context and dialogue of the Inuit communities' experiences would be lost and deprived of meaning. The 
holistic approach taken by the researchers is essential in deepening the reader's understanding around the importance of the natural environment on the wellbeing of people and create a deeper sense of urgency around the environmental crisis. Researchers need to be deeply reflexive of their bias, agendas and to ensure it does not influence their research. And if it does, to openly state it in the literature and position themselves. In addition, when working with the community and building deeper relationships, power dynamics need to be continuously deconstructed and minimized. Proper acknowledgement, in whatever ways the community decides, needs to be provided for their contribution to the research and knowledge production.

\section{Theoretical Framework of Literature Reviewed}

These literatures reviewed overall lacked explicit descriptions of their theoretical frameworks and researchers were absent in positioning their social locations and being selfreflexive. Only Willox et al.'s (2013) research was grounded in the foundation of anti-oppression framework. They allowed the dissemination, presentation and formation of the research to be directed by the Indigenous community and challenged the notion of "valid" knowledge production that dominates in western societies.

For example, Boetto and McKinnon (2013) although they looked at the negative impact of climate change of rural women in Australia, a feminist theoretical framework was clearly absent from their research. They briefly discussed how women are more vulnerable than men, however, they did not deconstruct the structures in rural settings that position women in roles that are dependent on their partners. Furthermore, they completely left out racialized and marginalized women from the study thereby not alluding to the underlying complexities, deeper forms of marginalization that these women experience in relationship to environmental problems. 
Moreover, they do not talk about how men can be supported to better assist women in taking on equitable roles. Similarly, Arsenault, Azam and Ahmad (2015) did not interview char migrant women in Bangladesh, only interviewing migrant men. No rationale was provided as to why females were disregarded. If the researchers operated from a feminist lens, it would erase this gap through being critical of the impacts that women experience due to interlocking oppressions that include patriarchy and sexism.

Lastly, the articles that pertain to using "green-social work", and "deep ecology" all lack centering and referencing of Indigenous knowledge. The concepts expressed by green social work and deep ecology parallels Indigenous teachings of interconnectedness and moving away from anthropocentric lens of the world that western knowledge emphasizes. Without centering or acknowledging Indigenous epistemologies, these frameworks then continue to perpetuate and harm Indigenous communities through appropriation.

\section{Summary of Literature Reviewed}

This literature review has clearly shown that social work education says hardly a whisper about the climate crisis and the natural environment in general. A recurring critique provided by the literature is the lack of emphasis on a systematic scale and targeting institutions which is required for larger change to occur. Social workers will need to work at all levels and with other disciplines to find collective solutions. This is especially needed because of the lack of research around social workers being active in the fight for climate justice. The majority of the studies that looked at the role of social workers and the environmental crisis were from Australia. This can be due to the fact that Australia's social work code of ethics explicitly states that social workers have a responsibility to create sustainable futures and protect the natural world, which is gravely absent 
in the code of ethics in Canada (Bowles, Boetto, Jones, \& McKinnon, 2016). A radical shift in the paradigm of social work needs to occur for action around the environmental crisis.

Crawford (2015) discussed using a transformative framework to facilitate critical reflection and to significantly change perspectives, thus making it difficult to ignore the importance around immediate action necessary for climate justice. A potential challenge is crossing the threshold between conceptual thought and contextualized action. Thus, social work needs to radically shift the framework of person-in-the-environment to person-with-the-environment or viewing people as place (Alston, 2015). Zapf (2010) stresses that seeing people as place encompasses the conceptualization of the environment as having character, meaning, and emotional significance to human beings. To elaborate, this concept links the "destruction of landscapes, globalising forces and mass migration to the erosion of the critical connection of people to place and thus to be the undermining of well-being, community cohesion and connectedness" (Alston, 2015, p. 359). Furthermore, the dominant anthropocentric discourse must be dismantled and theoretical frameworks of ecological model along with indigenous perspectives is critical to centring this issue. As stated by Appleby et al. (2017), for social work to stay relevant it needs to take responsibility for and be responsive to emerging global issues, which impact all aspects of society.

As someone who considers Bangladesh home and is deeply concerned by the climate crisis that will negatively impact the country, I am deeply saddened and angered. The literature review has strengthened my resolve and commitments to undertaking this research study that aim to call attention to how social work is almost entirely silent on the climate crisis. While the literature review highlighted the richness of qualitative research with the Inuit people, it also fortified my desire to carry out my qualitative research study with social work students. I longed to bring to light their voices about how they experienced social work education and the absence of climate 
crisis curriculum. However, as noted earlier the timelines for the completion of the MRP did not permit me to complete the qualitative study. Nonetheless, the literature review has emboldened me to carry on with my topic and to put forth the thesis that social work education omits climate crisis curriculum and to propose four responses to this lacuna in social work. Towards this end, my next section entails my explicit discussion of the theoretical framework that informs my approach to arguing the above noted thesis statement. 


\section{Theoretical Framework}

In this paper, I will utilize the theoretical frameworks comprised of anti-racism and anticolonialism.

\section{Anti-Racism Framework}

Anti-racism centers and deconstructs white supremacy, and Canada as a settler country. This is critical in teaching the history of oppression to affected groups, so that community members can understand, articulate and recognize the forces that oppresses people and communities. Furthermore, it is essential to raising political consciousness which is a part of the process of decolonization (Freire 1973; Shor \& Freire, 1987).

However, anti-racism similarly acts as a blanket term for marginalized people to avoid critical reflection, discomfort and complicatedness in the oppression of Indigenous peoples on colonized land (Lawrence \& Dua, 2005). Often land rights and sovereignty of Indigenous communities are lost in the discourses of anti-racism and racialized people on Turtle Island forget that they are living on lands stolen from Indigenous peoples (Lawrence \& Dua, 2005).

\section{Anti-Colonial Framework}

Concepts like postcolonialism, facilitate the ability of academics to position colonialism as being something of the past, as in colonialism is over and now you can work towards undoing the impacts of colonialism. However, colonialism is still operating in more covert ways. Anticolonialism involves the recovery of traditional knowledge as a strategy that resists the replacement of Indigenous ways and knowledges with Western epistemologies. Simpson (2004), states that anti-colonial strategies foster the political mobilization to stop the colonial "attack on 
Indigenous Knowledge and Indigenous Peoples" (p. 381) and "require the recovery of Indigenous intellectual traditions, Indigenous control over Indigenous national territories, [and] the protection of Indigenous lands from environmental destruction" (p. 381). Through using the term and concept of 'anti-colonialism' it centers the reality and current presence of the structures and practices of (settler) colonialism. Moreover, it creates space for interpreting the experiences of colonized peoples on their own terms and understandings of experiences not forced through Eurocentric lenses (Carlson, 2017). Thus, a decolonizing social work disrupts the discourse of 'othering', the dominant practice of outsider-led social work interventions and research methodologies that privilege the Western gaze (Carlson, 2017). Indigenous people can reclaim their voices and their collective post-colonial identity can emerge (Silver, Ghoayshi, Hay, \& Klyne, 2006).

\section{Climate Crisis in Context of The Anti-Racist and Anti-Colonial Lens}

Benedict Anderson's reference of nations being communities of imagination (Thobani, 2007) speaks to the narrative around white colonizers exalting themselves as founders of nations such as Canada and viewing racialized groups as "others" and threats to their collective welfare and prosperity. Through the creation of outsiders and nationals, outsiders are seen as threats to the nationals, thereby they need to be controlled, assimilated or annihilated. On the other hand, nationals are "deemed the legitimate heir to the rights and entitlement of the state" (Thobani, 2007, p. 3). National subjects are attributed the qualities of being civil, compassionate, valuing multiculturalism and the underlying conception of being white. If they fail to live up to these qualities, they are treated as exceptions, their shortcomings seen as individualistic qualities and isolated from the community. Contrarily, failings of outsiders are viewed as being reflective of the inadequacies of their community, of their culture, and entire 'race', while their successes are treated as exceptions (Thobani, 2007). This creation of a binary involving nationals and outsiders sets the 
premise of certain bodies being able to benefit from the nation while others are kept under control and marginalized.

Central to rise of the nation state is the concomitant destruction, exploitation, and domination over the natural world. In other words, while white nationals were exalted as proper citizens of the country, the natural world came under the control of the nation. This control has led to widespread destruction and the environment, theft of land from Indigenous peoples, and abuse of the land.

The treatment of Indigenous and Black communities is a parallel to the destruction of the planet. When European settlers arrived to colonize Canada, the land was seen as a form of dispensable resource to use for capitalization, profit, and human habitation. Indigenous communities were an obstacle for economic progress and the comfort of European settlers. The Indigenous peoples' epistemology of life was labelled as uncivilized and genocide was used in order to "civilize" people into the European life. The genocide led to a shortage of workers to provide labour for the settlers and thus African people were used as slaves and seen as a resource to use and dispose of as the colonizers pleased. The dehumanization of people is a form of establishing power so that the settlers can continue to make profits off of the suffering of those subjected to domination. This is how the capitalistic societies abuse and continue to strip the land.

In Canada this can been seen through the Trans Mountain Pipeline, that will continue to have a detrimental impact on the environment adding to the climate crisis. Moreover, it directly impacts the wellbeing, mental, physical, and spiritual health of Indigenous peoples. CanadaRepublic of Georgia Foreign Investment Promotion and Protection Agreement, FIPA, which remains in place until 2045, was signed to ensure that China got a pipeline built from Alberta to 
BC, among other benefits (Livesey, 2017). This poses an immense threat to Squamish territory, as it will carry more than 21,000 enormous oil tankers, the minimum amount, over the next 50 years; the pipeline will be carrying diluted bitumen (Khelsilem, 2018). Diluted bitumen is the most toxic oil and a single spill will jeopardize the ocean and kill the Salish Sea (Khelsilem, 2018). The continual choices by settlers to exploit the land, water, plants and animal species, without consultation with Indigenous peoples is an ongoing issue since the first contact by the European colonizers.

In conclusion, anti-racism and anti-colonialism are theoretical frameworks that guide my grappling with the current climate crisis, how this crisis is inseparable from colonialism, capitalism, racism, and ongoing theft of land by colonizers. This theoretical framework, I contend, also offers me the most effective way for understanding how social work education gravely ignores the climate crisis and for configuring responses to this gap in social work. Moreover, as a Bangladeshi woman and social worker, this theoretical framework provides me with a way of understanding the current climate crisis facing my home country. In this manner the anti-racism and anti-colonialism theoretical frameworks are, I argue, effective for understanding both local, national, and global issues around the climate crisis.

In the following section, I will now address the second part of my thesis statement, namely by proposing four solutions to the gap in social work education around the climate crisis. To reiterate these four solutions are the following: 1) to insert ethical obligations on the part of social workers to address climate change and environmental justice within the social work code of ethics, 2) to expand the person-in-environment focus to include nature and environmental justice, 3) to embrace a transformative learning paradigm, and 4) to implement a mandatory course on climate crisis. 


\section{Discussion}

The literature review has clearly shown that a striking and alarming gap in social work education curriculum is the climate crisis. Jones (2013) reviewed the inclusion of the natural environment in the Australian social work education curriculum and concluded that there is a striking omission of this topic. In addition, Shaw (2013) found that over two-thirds of the social work students $(67.56 \%)$ stated that their education did not discuss the climate crisis and that $90.08 \%$ believed that these issues should be addressed in the school of social work. This parallels the situation in Canada. A search looking at the terms "social work education" and "climate change" or "green social work" and "Canada" on the database of University of Calgary, Toronto and Ryerson illustrates the scarcity of Canadian studies on the topic with only a handful of publications. While some social work studies in Australia have addressed the climate crisis, little or no social work curriculum in Canada deals with this matter. For this reason, I contend that the absence of climate crisis curriculum in Canadian social work education is a fact, and the implications of such a gap is highly problematic. The gap in curriculum leads to social workers in the field who have little to no awareness or knowledge of climate issues and the inevitable populations that they will come into contact with in their practice who have suffered the consequences of the impacts of this crisis. This argument constitutes the first part of my thesis statement.

The negative impact of social work education's omission of curriculum dealing with the climate crisis is that it reproduces racism, colonialism, white supremacy and capitalism because the climate crisis disproportionately impacts developing nations and racialized and Indigenous populations throughout the world. Philip Alston, UN special rapporteur on extreme poverty and human rights, spoke about the risk of a "climate apartheid scenario in which the wealthy pay to 
escape overheating, hunger, and conflict, while the rest of the world is left to suffer" (Alston, 2019, p. 14). Due to colonization and capitalistic domination of the globe, marginalized communities are disproportionately represented by racialized, Black and Indigenous people. To be sure, this problematic resonates with the situation in my home country of Bangladesh. Alston's (2019) report highlights how the greatest negative impacts of the climate crisis is felt by those living in poverty, with many losing access to adequate food and water. As stated by Allison in the "UN expert condemns failure to address the impact of climate change on poverty" (n.d.), "Climate change threatens to undo the last 50 years of progress in development, global health, and poverty reduction," (pp.3). Developing countries will bear an estimated $75 \%$ of the costs of the climate crisis, the report said, despite the poorest half of the world's population causing just $10 \%$ of carbon dioxide emissions. The climate crisis will not only threaten access to basic rights to life, water, food, and housing for hundreds of millions of people, but also democracy and the rule of law.

Ashfaq Khalfan at Amnesty International regarded the climate crisis as a “... human rights issue precisely because of the impact it's having on people... [countries]... that fails to take any feasible steps to reduce greenhouse gas emissions is violating their human rights obligations" (Carrington, 2019, p. 15). Moreover, he stated that Amnesty planned to target governments and fossil fuel companies. He explained, "We need everybody to live up to their responsibilities to act on climate change and protect human rights" (Carrington, 2019, p. 16).

In the following sections, I now turn my attention to the latter half of my thesis statement: what can be done to address this problematic gap in social work education. 
It is crucial to include the climate crisis into the practice of social work. Some ways are to explicitly address the natural environment in the Canadian social work Code of Ethics, so that social workers can clearly see and respond to the mandate around the responsibility of the profession to address this social justice issue, and transformation of the framework of social work education.

\section{Including the Climate Crisis in Code of Ethics}

The first solution that I would like to propose as a way to address the gap in social work education curriculum around the climate crisis is by inserting this matter right into the social work code of ethics. As defined in the Canadian Association of Social Workers (CASW, 2005), under the code of ethics, "Value 2: Pursuit of Social Justice, social workers are governed to provide resources, services and opportunities for the overall benefit of humanity and to afford them protection from harm" (p. 9). The principles are outlined as follows (CASW, 2005, p. 9):

- Social workers uphold the right of people to have access to resources to meet basic human needs.

- Social workers advocate for fair and equitable access to public services and benefits.

- Social workers advocate for equal treatment and protection under the law and challenge injustices, especially injustices that affect the vulnerable and disadvantaged.

- Social workers promote social development and environmental management in the interests of all people 
These principles, especially the last point, mandate social workers to responsible for advocating on social justice issues that impact all humanity and manage the environment of people so they can thrive. As mentioned previously, The Council on Social Work Education, CSWE, (Dewani, 2011), declared the climate crisis as the greatest threat to humanity. Thus, social workers are regulated and obligated to confront the crisis.

The limitation of the Code of Ethics produced by the Canadian Association of Social Workers is that it does not explicitly state anything about the natural environment. To include the environment in the companion document to the Code of Ethics can be seen as a mere afterthought, without any primacy or priority.

Within social work is an anthropocentric understanding of the environment, which focuses on the sociocultural environment and not the climate crisis (Melekis \& Woodhouse, 2015). This is undoubtedly evident in social work education. As previously noted Jones (2013) found that the natural environment is almost completely absent from the social work curriculum. This parallels the situation in Canada. A search looking at the terms "social work education" and "climate change" or "green social work" and "Canada" on the databases located in the libraries of University of Calgary, Toronto and Ryerson illustrates the scarcity of Canadian studies on the topic with only a handful of publications. To combat this striking gap, the climate crisis must be inserted right into the CASW Code of Ethics. This will obligate social work schools across Canada to place greater curricular emphasis on the climate crisis.

This curricular shift to include a focus on the climate crisis, will lead to a focus on hiring more social work professors with more expertise in the climate crisis and environmental justice. Likewise, more professors with this professional training and expertise will lead to more 
publications and research in the area of climate crisis, which in turn will foster more graduate student work in this area, alongside activist campaigns, conferences. However, to get here, I assert that inserting the climate crisis into the Code of Ethics is a necessary place to start.

\section{Expanding the Person-In-Environment Approach to include Nature.}

The second solution I propose for addressing the gap in social work education around the climate crisis is to focus on a transformation framework that involves expanding the person-inenvironment approach to include nature. Numerous authors are calling for a transformative practice where the person in the environment approach is expanded to encompass the effects of the natural environment on the wellbeing of people. This expansion of the concept can take into account environmental refugees, mental health challenges due to the climate crisis, such as climate depression/anxiety/grief, and Indigenous peoples' ongoing fight for land sovereignty, etc. As it currently stands, the person-in-environment approach in social work does not concern itself with nature, but rather focuses on the client in relation to family, friends, neighbours, and institutions such as education, healthcare, criminal justice, employment and housing.

Social work has always looked at the 'environment' when assessing a person's circumstance, however, the professional has only centered the sociocultural and psychosocial environment and disregarded the physical and natural environment (Melekis \& Woodhouse, 2015). To address the climate crisis in social work "we should first look to broaden our view of the person in environment to include a more holistic view of human behaviour and the inclusion of the natural world" (Coates, 2003, p. 178). In doing so, we must be careful to not keep to the Western model of people in relation to the natural world, a relationship of taking, an anthropocentric outlook. Through decolonization we are able to highlight the relationship to land and acknowledge the 
interdependence of nature to human beings. Hoff and Polack (1993) speak about the importance of an ecological focus:

The ecological model of science emphasizes that human beings are organic, intrinsically embedded in the larger ecosystem. We are in a relationship and exchange with the rest of nature. Life is evolutionary, dynamic and adaptive. From this wholistic perspective we affect and are affected by our environment. (p. 207)

Coates (2005) states that a paradigm shift is vital in the professional for this shift to occur.

The absence of climate crisis curriculum in social work may also be linked to the lack of expertise in this area by the current professoriate. Thus, professors may need professional development to assist them in deepening their understanding of issues of climate crisis. That training needs to be grounded in anti-racism and anti-colonial frameworks, as racialized people and Indigenous communities are disproportionately impacted by the crisis. As a Bangladeshi woman, I know this reality first hand. Currently, many schools of social work in Canada have adopted an anti-oppressive lens which historically arose in contestation of anti-racism (Pon, Giwa, \& Razack, 2016). Although anti-oppression addresses the power imbalances between those with power and those without, it is a blanket conceptualization that caters towards white settlers, as it often does not center around the difficult issues of white supremacy. Thereby, white settlers who embrace anti-oppression approaches to social work do not need to deal with the discomfort around conversations of race and colonization (Pon, Giwa, \& Razack, 2016). White settlers do not need to critically reflect upon their complicity in perpetuating systems of oppression (Pon, Giwa, \& Razack, 2016). 
Anti-racist and anti-colonial frameworks are crucial as they center the impact of colonialism and bring forth Indigenous perspectives. Climate justice needs to center around Indigenous sovereignty and right to the land. When using an anti-colonial lens, it is important that Indigenous knowledges are not appropriated. As can be seen in eco-social work, green social work, and in deep ecology, concepts of Indigenous frameworks are alluded to, however, reference to these frameworks are not linked to Indigenous epistemologies. Neither is Indigenous sovereignty nor rights to land claims discussed in green social work discourses. It is important to center the voices of Indigenous peoples and work collaboratively with Indigenous peoples in deriving impactful solutions to climate change. However, it needs to be done in a way that honours and respects their knowledge and worldviews and does not appropriate and repackage them as our own, new ideas, as has been typical in the Western world. As Tashka Yawanawa put it: "We are tired of anthropologists, environmentalists, church---related organizations, and other specialists speaking for us and using us for their self-interest. Please respect our self-determination to make our own decisions" (cited in Betancourt, 2013, p. 1). It is imperative that Indigenous peoples take the lead on this work and that they are in the lead throughout the entire process. These perspectives are critical in our understanding of how to reconnect people back to their environments, which will be a crucial part of how we are going to shift the cultural consciousness on these issues (IPCC, 2014a).

In conclusion, the second solution I propose is that the person-in-environment approach in social work be expanded to include the natural environment. I assert that this expansion must be done utilizing an anti-racism and anti-colonialism framework, while being very careful to not appropriate Indigenous knowledge. The expansion of the person-in-environment approach to 
include nature, will from a critical perspective be informed by an understanding of how colonialism, racism, and white supremacy are implicated in the current climate crisis.

\section{Transformative learning theory.}

The third solution to the gap in social work curriculum that I propose is transformative learning theory. Transformative learning theory, developed by Mezirow (2006), describes how people develop and use critical self-reflection to consider their beliefs and experiences, and over time, change dysfunctional means of seeing the world. Mezirow (2006) was interested in peoples' worldviews and factors that lead to people changing their frames of references. Frames of reference are defined as mental pathways through which individuals make sense of personal experiences and that predetermine a person's cognitive, emotional and behavioural responses to new experiences. In other words, they are like filters that "shape and delimit our perception, cognition and feelings by predisposing our intentions, beliefs, expectations and purposes" (Mezirow, 2006, p. 26). Mezirow describes transformative learning as "the process by which we transform problematic frames of reference $[\ldots]$ to make them more inclusive, discriminating, open, reflective and emotionally able to change" (2009, p. 26).

To welcome and create a space for shifts in perspectives around the climate crisis, scenariobased learning provides a great avenue to have social work students critically examine their views. Scenarios where the natural environment is connected to provide a holistic and intersectional analysis will allow students to understand how the climate crisis exacerbates oppressions of marginalized populations. Connecting that with an anti-racist lens, student will see how the wealthy are often able to use their financial resources to mitigate the harm that comes from

environmental disasters, illness, mental health and job instability. With an anti-colonial 
framework, it is possible to foster more in-depth analysis of how the climate crisis continues to impact the physical, mental, spiritual health of Indigenous communities.

\section{Including a Mandatory Course on Climate Crisis}

The fourth and final solution I propose as a way to deal with the absence of the climate crisis in social work curriculum is the implementation of a mandatory course in social work on climate crisis. In this course social work students will learn about the interconnectedness of the climate crisis in relation to social inequity. Environmental destruction is tied to the Western notion of individualism, consumerism and unmitigated growth leading to mass levels of pollution and the extraction of irreplaceable resources (Hawken, 1993). Moreover, individualism and anthropocentrism breeds communities of isolated individuals and families. Mary Clark (1989) writes: "more and more are Western societies . . . becoming assemblages of unhappy, alienated individuals, proud of their freedom from dependence on others, unaware that it is the rejection of their mutual relatedness that creates their unhappiness" (p. 311). Addressing the climate crisis forces a perspective shift in the direction of interconnectedness of all ecology as "we now share one another's fate [and] it is increasingly clear that promoting the well-being of others directly promotes our own" (Elgin, 2000, p. 115). The realization of the ways in which the environment and community can strengthen each other also "enable[s] the social welfare sector of society to significantly influence the quality of . . . life experienced by all those who need and want social welfare services" (Hoff \& McNutt, 1994, p. 6). Through this concept of interconnectedness social workers can combine the climate crisis to other forms of theoretical frameworks, such as a feminist lens, or an anti-colonial lens, to deepen their critical reflection of injustice and ideas around holistic solutions. 


\section{Conclusion}

In this paper, I have argued that the social work curriculum ignores the climate crisis. Additionally, I have advanced four ways to address this gap in the curriculum. These four responses are: 1) to insert ethical obligations on the part of social workers to address climate change and environmental justice within the social work code of ethics, 2) to expand the personin-environment focus to include nature and environmental justice, 3) to embrace a transformative learning paradigm, and 4) to implement a mandatory course on climate crisis.

As identified by CSWE (2010), climate change is the number one threat to the social wellbeing of people of the century. The increased rate of climate related disasters is widening the gap between those that can most easily adapt versus those who are not. This gap is impacting vulnerable populations disproportionately (Alston, 2015). Climate change clearly threatens the psychosocial and social functioning of individuals and society at large, especially marginalized populations. Since the central solutions to dealing with climate change involve the need for policy changes by governments and businesses and a shift in social consciousness, as well as individual action, it is clear by the definition of the social work mandate by the CASWE (2008) that environmental issues such as climate change fall under the purview of social work.

For social work to incorporate and work towards climate justice, a paradigm shift in the profession is essential. The cultural mindset of Western social work that views the individual as separate from their natural environment acts as a limitation to the growth of the profession as it lacks the depth that comes from connections people have to place and nature. As previously noted, there is grief of loss habitats, places and trauma experiences after natural disasters. By not understanding how the natural environment is linked to grief or trauma caused by the climate crisis, social workers will miss a foundational piece to supporting individuals. In addition, social workers 
are not nearly active enough in taking action to advocate on the importance for government and corporations to address the climate crisis. An anti-colonial framework is crucial for highlighting Indigenous epistemologies where the individual and the natural world cannot be separated; rather, they must be viewed as interdependent and interconnected, as well as mutually reciprocal and reinforcing in how they influence one another. This expands the person-in-environment approach to social work to be more holistic. In the conversation around climate justice, land sovereignty needs to be addressed as well, and to have Indigenous sovereignty in the narrative of fighting for climate justice. In addition to an anti-colonial framework, an anti-racism lens needs to be incorporated as well to tackle the intersectionality of race when it comes to the disproportionate impacts of the climate crisis. Whiteness and capitalism need to be centered in how we address the climate crisis.

To shift the perspective of social work practice, transformative learning can be utilized to challenge people's norms. To deepen the understanding of the interdependence of nature and human wellbeing, case-studies of real-life examples, where the natural environment is introduced will allow students to connect and make links between the climate crisis and impacts civilization. This will also highlight how social injustices are exacerbated by the climate crisis. An expansion of the person-in-environment approach is also needed to have this paradigm shift. Educators of social workers need to teach about the role the climate has on the wellness of people and the earth in general. An anti-colonial and anti-racist framework need to ground the curriculum. However, the school needs to be mindful of not repackaging Indigenous knowledges into Western concepts and claiming the teaching as their own. Social work needs to stay relevant and incorporate environmental justice. 
The curriculum working group, which was formed by the Social Work Education's (CSWE) Educational Policy Accreditation in Higher Education (AASHE) (2009), developed a framework to assist in integrating environmental sustainability into the education and educational goals of social work (Melekis \& Woodhouse, 2015). With an educational framework that encourages reflexivity, "experiential and action-orientated learning, social work is well positioned to facilitate the ecological transformation that links the personal with the environmental, and manifests in individual and political action" (Melekis \& Woodhouse, 2015, p. 581).

In summary as a woman who considers Bangladesh home, I feel a deep rush of sorrow from knowing that millions of people will be displaced, and millions of species of plants and animals are at the threat of extinction because of the climate crisis. Environmental racism angers me, and I am deeply saddened by how marginalized and racialized peoples will end up paying the most for the climate crisis. My hopes are that I have been able to take these feelings and my love for Bangladesh in all its beauty and splendor and channeled it into this Major Research Paper. While I longed to bring to light the voices of students, I have, nonetheless, did my best to honour my passions, concerns, and anger to advance some ideas for change in social work. This change is surely needed, and long overdue. 


\section{References}

Almasy, S. \& Karimi, F. (2015, February 15). Boston has its snowiest month on record. CNN. Retrieved from http://www.cnn.com/2015/02/15/us/weather---winter---storm/

Alston, M. (2015). Social work, climate change and global cooperation. International Social Work, 58(3), 355-363.

Appleby, K., Bell, K., \& Boetto, H. (2017). Climate change adaptation: Community action, disadvantaged groups and practice implications for social work. Australian Social Work, 70(1), 78-91.

Arsenault, M. P., Azam, M. N., \& Ahmad, S. (2015). Riverbank erosion and migration in Bangladesh's Char lands. Environment, migration and adaptation: Evidence and politics of climate change in Bangladesh, AHDPH, Dhaka, 3, 41-62.

Beaumier, M. C., \& Ford, J. D. (2010). Food insecurity among Inuit women exacerbated by socioeconomic stresses and climate change. Canadian Journal of Public Health, 101(3), 196-201.

Berkes, F., \& Jolly, D. (2002). Adapting to climate change: social-ecological resilience in a Canadian western Arctic community. Conservation Ecology, 5(2). Retrieved from http://dlc.dlib.indiana.edu/dlc/bitstream/handle/10535/2746/Berkes.pdf?sequence=1\&isAll owed =y

Boetto, H., \& McKinnon, J. (2013). Rural women and climate change: A gender-inclusive perspective. Australian Social Work, 66(2), 234-247.

Bowles, W., Boetto, H., Jones, P., \& McKinnon, J. (2018). Is social work really greening? Exploring the place of sustainability and environment in social work codes of ethics. International Social Work, 61(4), 503-517. 
Carlson, E. (2017). Anti-colonial methodologies and practices for settler colonial studies. Settler Colonial Studies, 7(4), 496-517.

Clark, M. (1989). Ariadne's thread: The search for new modes of thinking. London: The Macmillan Press Ltd.

Case, R. A. (2017). Eco-social work and community resilience: Insights from water activism in Canada. Journal of Social Work, 17(4), 391-412.

Chilisa, B. (2012). Postcolonial Indigenous research paradigms. In Indigenous research methodologies (pp.97-128). Los Angeles: SAGE.

Coates, J. (2011). Social work and the environment: A progressive step forward. Global Alliance for a Deep Ecological Social work. Retrieved from http://ecosocialwork.org

Clapp, J. (2011). Food. Cambridge, ENG: Polity Press.

Clapp, J. \& Cohen, M. J. (2009). The global food crisis: Governance challenges and opportunities. Ontario, CAN: Wilfred Laurier University Press.

Conley, J. (2019). With 2019 Predicted to Be Among Planet's Hottest Years, France's $114^{\circ}$ Heat Is 'Absolutely Consistent' With Warnings of Climate Crisis. Retrieved from https://www.commondreams.org/news/2019/06/28/2019-predicted-be-among-planetshottest-years-frances-114o-heatabsolutely?fbclid=IwAR2F2KjF8gi0aa6Fpjk5euDQIYuhA2KhVc7QO_IVhiCzBHWergAI RylDgSc

Cost of fire protection. (2019). Retrieved from https://www.nrcan.gc.ca/climate-change/impactsadaptations/climate-change-impacts-forests/forest-change-indicators/cost-fireprotection $/ 17783$ 
Crawford, F., Agustine, S. S., Earle, L., Kuyini-Abubakar, A. B., Luxford, Y., \& Babacan, H. (2015). Environmental sustainability and social work: A rural Australian evaluation of incorporating eco-social work in field education. Social Work Education, 34(5), 586-599.

Creswell, J. W., \& Clark, V. L. P. (2017). Designing and conducting mixed methods research. Sage publications.

Cumby, T. (2016). Climate change and social work: Our roles and barriers to action. Retrieved from https://scholars.wlu.ca/cgi/viewcontent.cgi?article=2935\&context=etd

Drolet, J., Wu, H., Taylor, M., \& Dennehy, A. (2015). Social work and sustainable social development: Teaching and learning strategies for 'green social work' curriculum. Social Work Education, 34(5), 528-543.

du Pont, Y. R., \& Meinshausen, M. (2018). Warming assessment of the bottom-up Paris Agreement emissions pledges. Nature communications, 9(1), 4810.

Elgin, D. (2000). Promise ahead: A vision of hope and action for humanity's future. New York: William Morrow.

Elgot, J. (2013, December 13). Snow in Egypt for the first time in 100 years, reports say (PICTURES). Retrieved from https://www.huffingtonpost.co.uk/2013/12/13/snow-egyptmiddle-

east_n_4438571.html?guccounter=1\&guce_referrer=aHR0cHM6Ly93d3cuZ29vZ2xlLmN vbS8\&guce_referrer_sig=AQAAAM92tBuaVzBDBnj600L2qVjFhxPLtAMCFs4q_4ABF Q_V32nVZjEnYmluHC2vTpTNAJ8rwX5GXMzRmkXrK4JYhbw90HdI5pGtFf57bgPYQ _jLT0wE5Ar8F0UDrYaZslGc_41CnzEXc_9b-GVhIyxDtET7nRz_vkpwV8YawAuQJBnS

Environmental Defense. (2015, May 15). Statement by environmental defence's Dale Marshall on the Canadian government's weak pledge for the Paris climate summit. Retrieved from 
http://environmentaldefence.ca/articles/statement---environmental---

defence\%E2\%80\%99s---dale---marshall---canadian---government $\%$ E2\%80\%99s---weak--pledge--- paris---cli

Ferreras, J. (2015, April 5). Canada food prices are making it tougher to afford groceries. The Huffington Post Canada. Retrieved from http://www.huffingtonpost.ca/2016/04/05/ canada--food---prices_n_9621042.html

Forest Fires and Climate Change. (n.d.). Retrieved from https://climateatlas.ca/forest-fires-andclimate-change

Goulden, M. L., \& Bales, R. C. (2019). California forest die-off linked to multi-year deep soil drying in 2012-2015 drought. Nature Geoscience, 1.

Government of Canada. (2015, November 19). Canadian drought monitor. Retrieved from http://www.agr.gc.ca/eng/?id=1430766471261

Grandia, K. (2015, October 6). Canada election 2015: Where do the parties stand on climate change? Desmog Canada. Retrieved from http://www.desmog.ca/2015/10/06/canada--election---2015---where---do---parties---stand---climate---change

Harris, C., \& Boddy, J. (2017). The natural environment in social work education: A content analysis of Australian social work courses. Australian Social Work, 70(3), 337-349.

Hawken, P. (1993). The ecology of commerce. New York: Harper Business

Heatwave in India. (2019, June 10). Retrieved from

https://earthobservatory.nasa.gov/images/145167/heatwave-in-india

Hermann, P. (2014, April 30). Street collapses in Baltimore, washing away cars. The Washington

Post. Retrieved from https://www.washingtonpost.com/local/street---collapses---in--- 
baltimore---washing---away---cars/2014/04/30/89f6dcfa---d0b0---11e3---a6b1--45c4dffb85a6_story.html

Hoff, M. \& McNutt, J. (1994). Introduction. In M. Hoff and J. McNutt (Eds.), The global environmental crisis: Implications for social welfare and social work (pp. 1-11). Aldershot, England: Ashgate Publishers.

IPCC. (2014a). Summary for policymakers. In Climate Change 2014: Impacts, Adaptation, and Vulnerability. Part A: Global and Sectoral Aspects. Contribution of Working Group II to the Fifth Assessment Report of the Intergovernmental Panel on Climate Change [Field, C.B., V.R. Barros, D.J. Dokken, K.J. Mach, M.D. Mastrandrea, T.E. Bilir, M. Chatterjee, K.L. Ebi, Y.O. Estrada, R.C. Genova, B. Girma, E.S. Kissel, A.N. Levy, S. MacCracken, P.R. Mastrandrea, and L.L. White (eds.)]. Cambridge University Press, Cambridge, United Kingdom and New York, NY, USA, pp. 1---32.

IPCC. (2014b). Summary for policymakers. In: Climate Change 2014: Mitigation of Climate Change. Contribution of Working Group III to the Fifth Assessment Report of the Intergovernmental Panel on Climate Change [Edenhofer, O., R. Pichs---Madruga, Y. Sokona, E. Farahani, S. Kadner, K. Seyboth, A. Adler, I. Baum, S. Brunner, P. Eickemeier,B. Kriemann, J. Savolainen, S. Schlömer, C. von Stechow, T. Zwickel and J.C. Minx (eds.)]. Cambridge University Press, Cambridge, United Kingdom and New York, NY, USA.

Jones, P. (2013). Transforming the curriculum: Social work education and ecological consciousness. In M. Gray, J. Coates, \& T. Hetherington (Eds.), Environmental social work (pp. 213-230). 
Kramer, A. E. (2010, August 5). Russia, crippled by drought, bans grain exports. The New York Times. Retrieved from http://www.nytimes.com/2010/08/06/world/europe/06russia.html?_r=0

Lakritz, T. (2019, May 3). 10 sinking cities that could soon be underwater. Retrieved from https://www.insider.com/sinking-cities-climate-change-2019-5

Lawrence, B., \& Dua, E. (2005). Decolonizing anti-racism. Social Justice, 32(4): 120-143.

Leahy, S. (2019, May 06). One million species at risk of extinction, UN report warns. Retrieved from https://www.nationalgeographic.com/environment/2019/05/ipbes-un-biodiversityreport-warns-one-million-species-at-risk/

Li, J. (2016, March 30). High produce prices create 'a chain' of rising costs, distributor says. CBC News. Retrieved from http://www.cbc.ca/news/business/high---price---food---produce--distributor---1.3419355

Livesey, B. (2018). Did Canada buy an oil pipeline in fear of being sued by China?. Retrieved from https://www.theguardian.com/commentisfree/2018/may/31/justin-trudeau-kindermorgan-pipeline-china-did-he-fear-being-sued

McGrath, M. (2019, July 02). Climate change: Heatwave made 'at least' five times more likely by warming. Retrieved from https://www.bbc.com/news/science-environment-48838698

Melekis, K., \& Woodhouse, V. (2015). Transforming social work curricula: Institutional supports for promoting sustainability. Social Work Education, 34(5), 573-585.

Miller, S. E., \& Hayward, R. A. (2014). Social work education's role in addressing people and a planet at risk. Social Work Education, 33(3), 280-295. 
Mukheibir, P., Kuruppu, N., Gero, A., \& Herriman, E. (2013). Cross-scale barriers to climate change adaptation in local government, Australia. National climate change adaptation research facility.

(n.d.). UN expert condemns failure to address impact of climate change on poverty. Retrieved from https://www.ohchr.org/EN/NewsEvents/Pages/DisplayNews.aspx?NewsID=24735\&LangI $\mathrm{D}=\mathrm{E}$

Neuman, W. L. (2013). Social research methods: Qualitative and quantitative approaches. Pearson education.

NPR. (2013, September 8). How could a drought spark a civil war? Retrieved from http://www.npr.org/2013/09/08/220438728/how---could---a---drought---spark---a---civil--war

Pon, G., Giwa, S., Razack, N. (2016). Diversity and Social Work in Canada. Foundations of Antiracism and Anti-oppression in Social Work Practice, pp. 38-58. Don Mills: Oxford University Press

Pti. (2019). Delhi temperature: Delhi records all-time high of 48 degrees Celsius in June, heatwave to continue: Delhi News - Times of India. Retrieved from https://timesofindia.indiatimes.com/city/delhi/delhi-records-all-time-high-of-48-degreescelsius-heat-wave-to-continue/articleshow/69727572.cms

Quackenbush, C. (2018, July 05). Canada Heat Wave: Death Toll in Quebec Climbs to 34. Retrieved from https://time.com/5330635/canada-heat-wave-death-toll-quebec/

Ramsay, S., \& Boddy, J. (2017). Environmental social work: A concept analysis. The British Journal of Social Work, 47(1), 68-86. 
Rathbun, B. (2016, January 27). Record---breaking blizzard buries mid---Atlantic with over 2 feet of snow. Accuweather. Retrieved from http://www.accuweather.com/en/weather---news/ recap---blizzard---2016---washington---dc---new---york---city---philadelphia---baltimore-- northeast/54977271

Reklev, S. (2014, July 28). Drought hits China food production: Xinhua. Reuters. Retrieved from http://www.reuters.com/article/us---china---drought---agriculture---idUSKBN0FX0LD 20140728

Semeniuk, I. \& McCarthy, S. (2015, March 18). Complete shift to renewable energy within Canada's reach, academics say. The Globe and Mail. Retrieved from http://www.theglobeandmail.com/news/politics/complete---shift---to---renewable--energy--- within---canadas---reach---academics---say/article23513579/

Sarker, Maminul \& Huque, Iffat \& Alam, Mustafa \& Koudstaal, Rob. (2003). Rivers, chars and char dwellers of Bangladesh. International Journal of River Basin Management. 1. 61-80. Retrieved from https://www.researchgate.net/publication/232840901_Rivers_chars_and_char_dwellers_of _Bangladesh.

Shaw, T. V. (2013). Is social work a green profession? An examination of environmental beliefs. Journal of Social Work, 13(1), 3-29

Simpson, L. R. (2004). Anticolonial strategies for the recovery and maintenance of Indigenous knowledge. American Indian Quarterly, 373-384.

Sturmer, J. (2014, September 24). Climate summit: Humanity has never faced a greater challenge, UN secretary---general Ban Ki---Moon says. $A B C$ News. Retrieved from 
http://www.abc.net.au/news/2014---09---24/un---says---climate---change---biggest---ever--threat--- to---humanity/5764636

Syed, F., Syed, F., Meyer, C., McLaughlin, D., Energy, \& Energy. (2018, November 29). Canada's 'insufficient' climate policies would help increase global warming by $5 \mathrm{C}$, study finds. Retrieved from https://www.nationalobserver.com/2018/11/29/news/canadas-insufficientclimate-policies-would-help-increase-global-warming-5-c-study

Tasker, J.P. (2019). Ottawa may have overpaid for Trans Mountain by up to $\$ 1 \mathrm{~B}$, parliamentary budget officer says. Retrieved from https://www.cbc.ca/news/politics/trans-mountain-pbo1.5000212

The Weather Network. (2013, August 14). Has Canada's climate already changed? Retrieved from http://www.theweathernetwork.com/news/articles/has---canadas---climate---already--changed/11016

The Weather Network. (2015, December 4). St. John's, NL breaks record snowfall. Retrieved from http://www.theweathernetwork.com/news/articles/the---next---hot---spot---for---heavy--snow---in---atlantic---canada/60571

Union of Concerned Scientists. (2011). Climate hot map: Global warming effects around the world. Retrieved from http://www.climatehotmap.org/global---warming---effects/rain--and--- snow.html

Willox, A. C., Harper, S. L., Edge, V. L., Landman, K., Houle, K., \& Ford, J. D. (2013). The land enriches the soul: On climatic and environmental change, affect, and emotional health and well-being in Rigolet, Nunatsiavut, Canada. Emotion, Space and Society, 6, 14-24.

Zhang, Y. (2016). Climate change impacts: Floods and droughts. WWF Global. Retrieved from http://wwf.panda.org/about_our_earth/aboutcc/problems/weather_chaos/floods_droughts/ 
Zhao, A., \& Pearl, M. (2019, July 11). 'Climate Despair' Is Making People Give Up on Life. Retrieved from https://www.vice.com/en_us/article/j5w374/climate-despair-is-makingpeople-give-up-on-life?utm_source=pocket-newtab 